\title{
Universiteit
}

Leiden

The Netherlands

\section{The Challenges of Social Sustainable Globalisation}

Nieuwenhuys, E.C.; Kort, J.F. de; Nieuwenhuys, E.C.

\section{Citation}

Nieuwenhuys, E. C., \& Kort, J. F. de. (2006). The Challenges of Social Sustainable Globalisation. Neo-Liberal Globalisme And Social Sustainable Globalisation, 1-11. Retrieved from https://hdl.handle.net/1887/43268

Version: $\quad$ Not Applicable (or Unknown)

License:

Downloaded from: $\quad$ https://hdl.handle.net/1887/43268

Note: To cite this publication please use the final published version (if applicable). 


\title{
1. The Challenges of Social Sustainable Globalisation
}

\author{
Eva Nieuwenhuys and Foop de Kort
}

\subsection{INTRODUGTION}

The world economy is globalising. World trade is growing at a faster pace than world income, indicating that countries are increasingly becoming interdependent on one another. According to mainstream economic thinking, globalisation is a good thing. One of the founding fathers of economic thinking, Adam Smith, ${ }^{1}$ already emphasized the importance of the labour specialisation and the exchange of surplus output as a source for economic growth. He pointed out that specialising and trading the surplus made sense for a private family and a country alike. The only limitation would be the extent of the market. The arguments for free trade and open economies were further elaborated upon by David Ricardo, ${ }^{2}$ who formulated the theory of comparative costs, which until today forms the very basis for the economic praise of the global economy.

The level of modern analysis is more sophisticated than that presented by either Smith or Ricardo; however, modern analysis is also less explicit with regard to the moral and social consequences of economic policies. The classical writers addressed the political economy, rather than merely economics. ${ }^{3}$ Neo-classical economists generally regard economics as a value-free science and often consider that the process of liberalisation is a sort of natural phenomenon. ${ }^{4}$ Under this view, the globalisation process is 'explained' from the perspective of technological developments which

${ }^{1}$ A. Smith, An Inquiry into the Nature and Causes of the Wealth of Nations (Liberty FundIndianapolis 1976, first published in 1776).

${ }^{2}$ D. Ricardo, Principles of Political Economy and Taxation (Dent-London 1973, first published in 1817).

${ }^{3}$ M. Blaug, Economic Theory in Retrospect, 5th edition (Cambridge University PressCambridge 1996) discusses the importance of both Smith and Ricardo to modern economic thinking.

${ }^{4}$ See in this regard R. Went, Grenzen aan de Globalisering? (Het Spinhuis-Amsterdam 1996), pp. 3-9. 
inevitably and irreversibly result in increasing global competition, the liberalisation of national markets, the privatisation of some parts of the public sector and the subordination of the state, culture and the natural world to the demands of the market.

In recent years, neo-classical economists have acknowledged the importance of a legal and institutional framework embodying the market mechanism, but, true to nature, economists have focused their attention on the efficiency enhancing or efficiency disturbing characteristics of the institutional framework. Globalisation and the opening up of economies are credited with economic growth. This claim, however, does not go unchallenged. Rodrik, ${ }^{5}$ for instance, points out that the alleged benefits of this openness are merely potential in that they can only be finally realised if complementary domestic policies and institutions are in place. He credits social and political institutions for their ability to handle external shocks that arise as a result of the openness. He also points out that development strategies, such as the Import Substitution Industrialisation of the 1960s or the export oriented development of the Asian economies in the 1980s, produced good growth results with relatively high levels of government intervention. Other commentators, such as Sen, ${ }^{6}$ assert that economics is not a value-free science. They argue that the present process of globalisation fails to take into account human, moral, social and cultural values in that it only gives weight to economic values formulated by institutions that are particularly focused on the operation of the free market.

Cultural and political philosophy writers often identify the present process of globalisation as 'neo-liberal globalism'. ${ }^{7}$ Neo-liberal writers find their inspiration in the moral philosophical writings of Adam Smith and his contemporaries, advocating that the interest of the community is the sum of the interests of its members, and that "an invisible hand" furthers social ends. According to Smith, the state has only three duties: the provision of military security, the administration of justice, and the erecting and maintaining those needed public works and public institutions that are not profitable for individuals to operate. Neo-liberal writers build on this individualistic and utilitarian approach to argue that human beings ought to be regarded as free, rational thinkers who act

${ }^{5}$ D. Rodrik, The New Global Economy and Developing Countries: Making Openness Work (Overseas Development Council-Washington 1999), pp. 12-14.

${ }^{6}$ See A. Sen, Development as Freedom (Knopf-New York 1999).

7 See for instance R. Safranski, Wieviel Globalisiering verträgt der Mensch? (Carl Hanser Verlag-München 2003) or J. Gray, False Dawn, Delusions of Global Capitalism (Granta BooksLondon 1998). 
egoistically, who can direct themselves and their environment and who are, therefore, responsible for their own welfare. ${ }^{8}$ In pursuit of their aims, human beings promote their own interests and subordinate everything else to those interests. Since human beings possess 'reason', they feel that they are entitled to elevate themselves above animals and nature. Human beings base their actions on a utilitarian ethic and regard nature, animals and other human beings in terms of their utility in satisfying their own, individual wishes and needs, which are insatiable due to their unlimited nature. ${ }^{9}$ Globalisation is part of this pursuit.

According to neo-liberals, people striving for maximum satisfaction of their desires, are willing, where necessary, to take into account the desires of others and of nature in so far as to do so is in their well-considered self-interest and is economically profitable. People regard the free market as the most suitable instrument through which to provide for their own needs and to strive towards economic growth and market efficiency in general. In their well-considered self-interest and on the basis of human reason, arising from a need for mutual commitment, people enter into a notional social contract with each other. On this basis, they share a limited moral duty with regard to each other to arrange for peace and security and to share what they consider a necessary minimal amount of collective goods and services. Globalisation under this approach promotes social cohesion within the world order and integrates countries, people and legal entities into the world economy by linking people worldwide with each other by using information and communication technology.

As for the rest, society leaves people free to satisfy their needs through mutual competition in the private sector - through the market. It is important to note that neo-liberals do not distinguish between absolute needs - those which have to be satisfied in order to subsist as human beings - and relative needs - those which have to be satisfied because they contribute to human welfare in the sense of material wealth, but regard all human needs as equal. On the basis of human reason, human dignity and the system of free market production, they expect a universal world order to arise in which the classical rights of freedom and the unfettered exercise of rights of ownership and contractual freedom will one day apply throughout the world and provide humanity worldwide with greater economic wealth. With respect to the distribution of

\footnotetext{
${ }^{8}$ See in this regard F. Fukuyama, The End of History and the Last Man (Penguin BooksLondon 1992).

${ }^{9}$ With regard to the striving after maximum satisfaction of material desire as an attitude to life and the assumed scarcity which results from infinite human needs, see R. Claassen, Het eeuwig tekort, een filosofie van de schaarste (Ambo-Amsterdam 2004).
} 
goods and resources to satisfy needs, an increase in inequality is permitted as long as those who receive the least also benefit. ${ }^{10}$

In this book, the authors point out that neo-liberal globalism does not offer viable and effective solutions to such worldwide social problems as poverty, environmental issues (particularly the imminent shortages of energy and water as well as the loss of biodiversity), increasing breaches of human welfare by forms of excessive consumption, the loss of cultural diversity, the disintegration of states, the increase in ethnic and religious conflicts, et cetera. This book focuses on the social dimensions of globalisation. Its authors discuss such dimensions from various philosophical, cultural, ethical and legal perspectives. "Neo-liberal Globalism and Social Sustainable Globalisation" is an interdisciplinary approach to the process of globalisation. Here, philosophers, (political) economists, ethicists and lawyers with various specialisations (such as law and administration in developing countries, the sociology of law, international law and company law) give thoughtful consideration to the consequences of the globalisation process. On the basis of various philosophic theories, the authors explain the process of globalisation and discuss it from various perspectives. The authors subject the principles of globalisation to critical examination and address developments in legislation, administration and law enforcement related to the globalisation process. They discuss the advantages and disadvantages of deregulation and the internationalisation of trade, financial transactions and production, and shifts in the powers of national, transnational and international authorities. (Many public administrative functions have shifted from the public to the private sectors, such as the provision of drinking water, energy, education, transport et cetera.) The authors examine new forms of private selfregulation on the basis of which private parties carry out public tasks, and they assess to what extent these private parties cooperate with public authorities and civil society. The authors analyse the bottlenecks in the globalisation process from various perspectives and put forward ideas which may lead to solutions. In doing so, they make a contribution to the globalisation debate which also is likely to promote even further debate.

\subsection{OUTLINE OF THE BOOK}

This book represents an attempt to make a valuable contribution to the globalisation debate. Its authors discuss fundamental questions regarding the social exclusion of countries and of various peoples throughout the world, poverty and the economisation of values. The political, cultural

\footnotetext{
${ }^{10}$ With regard to the liberal politics of distribution, see R. Claassen, Het eeuwig tekort, een filosofie van de schaarste (Ambo-Amsterdam 2004), pp. 146-151.
} 
and social dimensions of society and the natural environment are in danger of being increasingly subsumed by the economic dimension. There is also considerable discussion here about which tasks and powers should be allotted to national governments and which to international governmental organisations, international non-governmental organisations and international corporations. This book further presents the question of whether neo-liberal globalism contributes to social cohesion within the world order and to the integration of countries, peoples and legal entities within the world economy or whether a different paradigm is necessary for a social sustainable globalisation process, a paradigm that would strike a balance between the economy, people, nature, culture, the individual and society.

The book is divided into three parts and twelve chapters. This introductory chapter is followed by Part One, comprised of four additional chapters. Part One discusses a number of philosophical assumptions pertaining to neo-liberal globalism. Questions are raised with regard to: the concept of humanity which underlies the theoretical basis of neo-liberal globalism; the approach to life which this theory compels people to adopt; and the concepts of human rights, welfare, freedom, social justice, morality and culture which flow from this theory.

Part Two, also consisting of four chapters, examines whether the present national and international normative institutional frameworks are adequate to bring about social sustainable globalisation or, alternatively, whether reforms in public administration are needed which would change the present internal and external power relationships in the world. Attention is given to international economic organisations such as the World Trade Organization (WTO), the International Monetary Fund (IMF) and the World Bank. Such questions are addressed as whether and to what extent membership of these organisations might be in the interests of developing countries. Further questions are addressed concerning programmes for law and public administration in developing countries, the existing international legal order and the need to amend each of these in line with global society. The problems of global water management are discussed as a key issue to achieve sustainable development.

Finally, Part Three, comprised of three chapters, discusses the role of non-state actors (NSAs) in the globalisation process. Consideration is given to the way in which international non-governmental organisations (INGOs) and international corporations might contribute to ensuring that the globalisation process is given form in a social sustainable manner.

Part One, devoted to questions about the philosophical assumptions of neo-liberal globalism, opens with the contribution from Gliteur who defends neo-liberal globalism. On the basis of a moral-rational approach that adheres to Kant and many other Enlightenment thinkers. Cliteur 
is of the opinion that human beings are free, rational, self-directed beings and that the true ideals of the Enlightenment are worth striving for. $\mathrm{He}$ argues that human nature is the same everywhere and that the rule of law and democracy should, therefore, someday be the norm everywhere. He further asserts that people are willing to subject themselves to the will of a state with limited powers in order to achieve a minimal but acceptable level of security. The rule of law is needed to limit the powers of a democratic government and, in doing so, to ensure that the minority is not arbitrarily subjected to the will of the majority. According to Cliteur, the model of the democratic rule of law is universally applicable because it corresponds to a concept of human nature which itself is universal. People can therefore actually observe that the liberal ideals of the rule of law and democracy have, in fact, acquired a global meaning. According to him, evidence supporting this assertion can be drawn from the examples provided by the numerous countries where the model has been adopted. Finally, Cliteur takes the position that economic, social and cultural rights have no place in neo-liberal globalism as freedoms. He asserts that freedom from want and freedom from fear are not truly freedoms, but a group of social commitments and aspirational ideals which, though valued, may or may not be taken on by the state as something in addition to its other constitutional obligations as a matter of political choice.

Visser challenges the neo-liberal globalism's optimistic view of the world as he approaches the present process of globalisation as an experiential-rational phenomenon rather than as a moral-rational phenomenon. He discusses Marx' important questions of whether and to what extent freedom can protect itself from the excesses of its most powerful promoter, the market. In connection with this question, Visser draws attention to Nietzsche, who was the first to reflect on the impacts of the transformation of civil society into an experiential society. The essential part of a civil society was the right of every citizen to his own unique experience, to conduct his life as he wishes. The question, however, is whether the individual is in a position to exercise his right in an authentic experiential way. In an experiential society, labour becomes more mass-based than ever before, and experience itself becomes a product of the market. According to Nietzsche, globalisation and the expansion of the experience market will lead experience itself to become ambiguous. The economic total administration of the planet, as Nietzsche calls it, will result in a loss of meaning, in nihilism.

The search for an 'authentic experience of being', however, requires a return to the sources or roots of culture-art, philosophy and religion. Visser argues that, in time, globalisation will not be able to limit itself 
to international agreements on trade and the environment. The European tradition of ontology of the present, according to him, shows that the excessiveness of the process also demands worldwide, radical self-reflection in the form of dialogues between cultures, each culture expressing itself from its own roots.

Nieuwenhuys, like Visser, stresses the importance of a multi-dimensional concept of humanity. She argues that the one-dimensional view of neo-liberal globalism results in the globalisation of the economy, but not of wealth, liberty, society, politics, democracy, environmental awareness, culture and morality. The assumed self-directedness and the level of personal responsibility which people supposedly have are complete fictions for many people, all the more because the morality of the market does not take any account of the way in which the distribution of wealth excludes entire peoples and countries. Some people require positive help and involvement with others because they lack access to the market due to their age or state of health; the ability to exercise rights to property or their freedoms; or even the competencies and skills necessary to conduct market transactions. According to Nieuwenhuys the concept of freedom implies negative and positive freedoms in the sense of opportunities for social participation and self-determination. Progress and development imply economic growth and social advancement. Therefore, a social sustainable process of globalisation must be built on economic values as well as social, ethical, cultural and ecological values inherent in the multidimensional view of human beings. Such a process of globalisation must be given substance through the work of global economic, social and political institutions which promote the interests of all states and all the world's citizens in a balanced way and on the basis of equality.

Buitenweg expands the discussion on negative and positive freedom by explicitly stating that adherence to the narrow definition of human rights as the classical civil and political rights, i.e. the absence of coercion, is inadequate to guarantee individual freedom. Rather than being a group of social commitments and aspirational ideals, as Cliteur sees them, Buitenweg regards economic, social and cultural rights as human rights on a par with the classical ones. Being deprived of these rights excludes people from a dignified existence. Poverty, or socio-economic deprivation, is not the consequence of a natural phenomenon, but of human action. It results from political and legal measures and constructions which prevent the poor from taking what the rich took in the past and that which is essential to the preservation of life and subsistence. This notion implies, according to Buitenweg, that poverty is not a breach of positive freedom, but rather of negative freedom. Socio-economic 
deprivation results from an act, namely the committing of a wrong. For instance, the poor are denied access to the means necessary for their subsistence. Therefore, a socially sustainable globalisation process requires combating poverty on the basis of economic, social and cultural rights and a policy regarding social justice which propagates a proper allocation of scarce resources.

Part Two of the book opens with De Kort, who presents an overview of economic insights on the advantages and disadvantages of free trade. Since free trade does not mean unorganised trade or, as a consequence of skewed economic power in the world, unequal trade, he explicitly discusses the importance of such international institutions as the IMF and the WTO. In the area of economic policy, these organisations already serve as a type of 'global government'. They strive towards economic growth and the eradication of poverty through deregulation and the introduction of a global free market with a 'level playing field' on which countries worldwide can compete with each other. Although the policies of these institutions are subject to criticism, De Kort argues that the benefits of membership for poor countries outweigh the costs.

In the next essay, Brus argues that human society at present already is a global society with regard to economic and social structures, peace and security, the environment, culture, religion, human rights and democracy. According to Brus, the process of social sustainable integration requires a change in international law in line with the new realities of global society. Traditionally, merely the law applicable to the relations between states, international law will increasingly become the law more appropriately tailored to serve a different, more global society. The interests of the global community as a whole will occupy a place more central within the entire system of international law. In addition, international economic law must serve the interests of all, both rich and poor, and must have adequate support and legitimacy in order to regulate a global economy which functions well. As developing countries express a desire for international economic law to emphasise solidarity as well as freedom, where the rich industrialised countries still hold considerable reservations in this regard, such institutions as the WTO, the IMF and the World Bank will have to pay more serious attention to the divide between rich and poor and make solidarity a principle of international economic law in the promotion of economic development and the combating of poverty in order to give this right adequate legitimacy.

Otto focuses on the question of how aid programmes for policy and law in developing countries can contribute to development and, thus, to sustainable globalisation. He criticizes well-wishing advocates of liberalism who regard law informed by an ideology of liberalisation as the nor- 
mative foundation for poor, authoritarian states with stifled economies that seek to embrace an alternative which might transform their societies into free, democratic and prosperous ones. According to Otto, experience has demonstrated that too often ill-advised and under-researched strategies have led to the introduction of all sorts of legislation which simply failed to work in practice or was even counter-productive. He further points out that, although the suggestion is frequently made that the programmes are technical and neutral, in practice they embrace regulatory models which give market mechanisms a wide berth to benefit certain groups and disadvantage others. Thus, they regularly miss their announced target, development which is conceived of and elaborated upon by Otto in a broad multi-sectoral sense and not merely with regard to the economic growth of particular groups. In addition to the fact that economic growth is a vital developmental aim, it is also closely related to progress in other areas: security, education, social justice, health, environmental management, democratisation, sound administration and realistic legal security under the rule of law. Sometimes economic growth conflicts with these other aims, and when this occurs, a reasonable solution must be found. The development of law together with policy in and for developing countries certainly should not always be based purely on economic research, but rather also on socio-legal research into the implementation of law.

In the fourth and final chapter of this section, Hildering looks at the consequences of neo-liberal globalism from the perspective of one of the important topics to the achievement of sustainable development, namely global water management. In many areas of the world, water is a scarce resource, and several billion people in the world do not have access to clean drinking water or sanitation. Furthermore, conflicts exist between the uses of water, such as for drinking, for fishing and for transport. Leaving the solutions for the worldwide water crisis to the free market, as advocated by neo-liberal globalism, is an illusory solution according to Hildering. She argues that water is not merely an economic asset, but also a social and ecological one which, therefore, must be protected as a multifaceted asset under international law. She further rejects the argument that because weak states often fail to manage water efficiently, an adequate water supply would be best served by privatised companies. In countries where the water supply has been privatised, water prices often increase without any plausible explanations related to better water management. Furthermore, weak states are unable to guarantee the security of long-term public interests, quality control and the regulation of water management in social and ecological respects. Hildering advocates the recognition of the right of access to water as a human 
right under which the right to use water to meet basic needs, i.e. for drinking and sanitation, would be given priority above other uses.

In Part Three of the book, the focus shifts to the importance of private actors in the realisation of sustainable globalisation. In his contribution, Vedder argues that social and moral problems arising from the globalisation process cannot be solved in traditional ways by public actors due to particular shortcomings which are characteristic of both international law, in general, and international economic law, in particular. Their reach is limited to acts of states. Alternatively, private actors, on the basis of informal rules, intervene in international relations and in the lives of individuals on a worldwide basis. Such intervention raises questions about the legitimacy of both the way in which these rules are created and the standards which they seek to uphold. Thus, Vedder argues that a way must be developed through which to hold private legal entities accountable for their actions. He focuses on INGOs, as important non-state actors, and discusses a number of issues that set these actors apart from states in terms of accountability. First, governments obtain consent for activities which intervene deeply into the daily lives of their citizens whereas INGOs tend to seek consent for far more limited types of activities, such as participation in trade negotiations. Second, in the case of states, the general citizenry are those whose consent is required, but in the case of INGOs it is not always clear who should be consulted with regard to consent issues. Finally, various states conform to different sets of laws, norms, and values depending upon their own particular cultures but INGOs operate internationally. Under which set of values, then, can the policies that they propose be assessed? Vedder recognises that the existence of the variety of cultural and moral differences make it difficult to accept even a modest concept of moral universalism, but he believes that all people can agree, in principle, on several normative principles and that this modest consensus can be reached, in principle, in two ways: on the basis of either abstract ethical theories or of extremely practical rules of thumb.

De Groot focuses on another important private actor that shapes the process of globalisation, namely the corporation, and asks whether and how the concept of corporate governance can contribute to a socially sustainable process of globalisation. He observes that under the influence of neo-liberal globalism the shareholder-oriented model of corporate law is dominant worldwide. Although De Groot acknowledges the benefits of this model, he argues that this legal form simply may not lend itself to consideration of social and environmental interests and may exclude interested parties other than shareholders and directors from the decision and policy-making processes. To contribute to sustainable development, companies must find ways to take account of the interests of 
others - their employees, suppliers, creditors, customers and other interested parties - as well as those of their shareholders. According to De Groot, developments within the concept of corporate governance itself already point in that direction.

Lambooy too, focuses on the position of corporations. In anticipation of better mechanisms through which to regulate the balance of power between governments, multinational companies and civil society, the concept of corporate social responsibility, according to Lambooy, could make some contribution. This concept embraces the ideas that multinational companies should operate in a socially responsible manner and that they should publicly report on their policies and behaviour to ensure that they can be held accountable by civil society. Efforts are underway to induce multinational companies to take account of widely supported ethical norms and values. In this regard, Lambooy draws attention to the codes of conduct issued by the United Nations (UN) and by the Organisation for Economic Cooperation and Development (OECD). Lambooy also examines the Sustainability Reporting Guidelines of the Global Reporting Initiative (GRI). She points out that a number of leading multinational companies already prepare sustainability reports which follow these GRI guidelines on a voluntary basis. These reports create transparency with regard to corporate behaviour towards such issues as the environmental, social and ethical aspects of business operations and activities and further allow for stakeholders to engage in a substantive dialogue with companies to exert influence on their policies and activities. Such transparency, according to Lambooy, is essential for sustainable globalisation.

\subsection{IN GONGLUSION}

This book and each of its diverse essays reflect the nature of the globalisation process and examine the principles on which this process is based. It raises important questions such as under what conditions globalisation can contribute to the worldwide integration of countries and its peoples and, in addition, to the emergence of an international order in which all peoples feel that they are bound to each other and in which all humanity enjoys liberty and economic well-being. The goal of furthering the understanding of these questions unites each of the authors whose individual approaches reflect vastly different viewpoints and demonstrate the complexity of the challenges.

Each person who contributed to the making of this book hopes that the reader will find that this book contributes to their knowledge of the philosophic, cultural, ethical and legal aspects of the phenomenon of globalisation. 